\title{
Polygonum orientale (EPersicaria orientalis; Polygonaceae) in Turkey re-discovered after 73 years and considerations about its status
}

\author{
Neval Güneş Özkan ${ }^{1} \mathbb{D}$ and Ayşe Yazlık,* \\ ${ }^{1}$ Düzce University, Faculty of Forestry, Department of Botany, Düzce, Turkey, 81620 Düzce, Turkey. \\ 2,* Düzce University, Faculty of Agriculture, Department of Plant Protection, Düzce, Turkey.
}

Corresponding author: ayseyazlik@duzce.edu.tr

\begin{abstract}
Polygonum orientale ( $\equiv$ Persicaria orientalis; Polygonaceae), a specie native to a wide region from India to Far East Russia and extending to North and South Australia. For this reason, in here, this taxon is recorded as a new alien species for Turkey. The species was first recorded in Turkey in the Marmara region (Sakarya province, Adapazarı district) in 1936. Subsequently, it was found in the Central Anatolia (Ankara province) in 1942, in the Eastern Black Sea Region (Rize province) in 1945, and finally in the South Eastern Anatolia (Urfa province) in 1947. Our finding represent was the first one in the Western Black Sea Region (Düzce province, Kaynaşlı district), 73 years after its last detection. Information about the current distribution and habitats of this species in Turkey, as well as its complete morphological description, were provided.
\end{abstract}

Keywords: alien, Black Sea flora, Düzce, ecology, habitat, new record

\section{Introduction}

The Polygonaceae family, which has the highest distribution in the Northern Hemisphere, is represented by 52 genera and an estimated 1552 taxa in the world (Roskov et al. 2019). These family members are defined as herbs, shrubs, rarely climbers or trees.

There are 10 genera under the Polygonaceae family in Turkey (Güner et al. 2012). Poligonum orientale, which is located under Polygonum, one of the largest genera of the Polygonaceae family, is accepted in many international references under the name Persicaria orientalis (TPL 2020, GBIF 2020, Roskov et al. 2019). However according to International Plant Name Index (IPNI) and the Plant List of Turkey Persicaria orientalis is a synonym of Polygonum orientale (IPNI 2020; Güner et al. 2012; Keskin 2012).

Polygonum orientale was first described by Carl Linnaeus in 1753, but was transferred to the genus Persicaria by Édouard Spach in 1841. Polygonum orientale ( $\equiv$ Persicaria orientalis) is a species native to a wide are ranging from India to Far East Russia and extending to North and South Australia. For this reason, this taxon is an alien plant for flora of Turkey, and it is currently considered as an alien invasive plant in some countries (WV-DNR 2009, Randall 2012, Kaufman \& Kaufman 2012).

The first record of Polygonum orientale in Turkey dated 1936 and refers to a collection from Adapazar1Sakarya. Later, the species was recorded in Ankara Province (1942), in the Eastern Black Sea Region, Rize Province (1945), and in South Eastern Anatolia, Urfa province (1947) (see Geven et al. 2008). 
As part of the DÜBAP project, we found of Polygonum orientale from a different locality, representing a re-discovering of the species after 73 years. Information about the distribution and habitats of this species in Turkey, as well as a complete description, were also given.

\section{Material and Methods}

Field surveys were carried out in Kaynaşlı district of Düzce Province (Western Black Sea Region) in July 2018. The site locality (Kaynaşl1, 40,7775 N, 31,32556 E) is located in A3 square according to the grid system in Flora of Turkey (Davis, 1967) (Fig. 1). Collected specimens were deposited in the herbarium DUOF (code according to Thiers, 2020 [continuously updated]).

We here accept the recognition of the taxon under the genus Polygonum Linnaeus (1753: 362), according to Güner et al. (2012). However, considering the importance of using acceptable plant names according to a common international standard, it will be useful to clarify what the accepted name of this species.

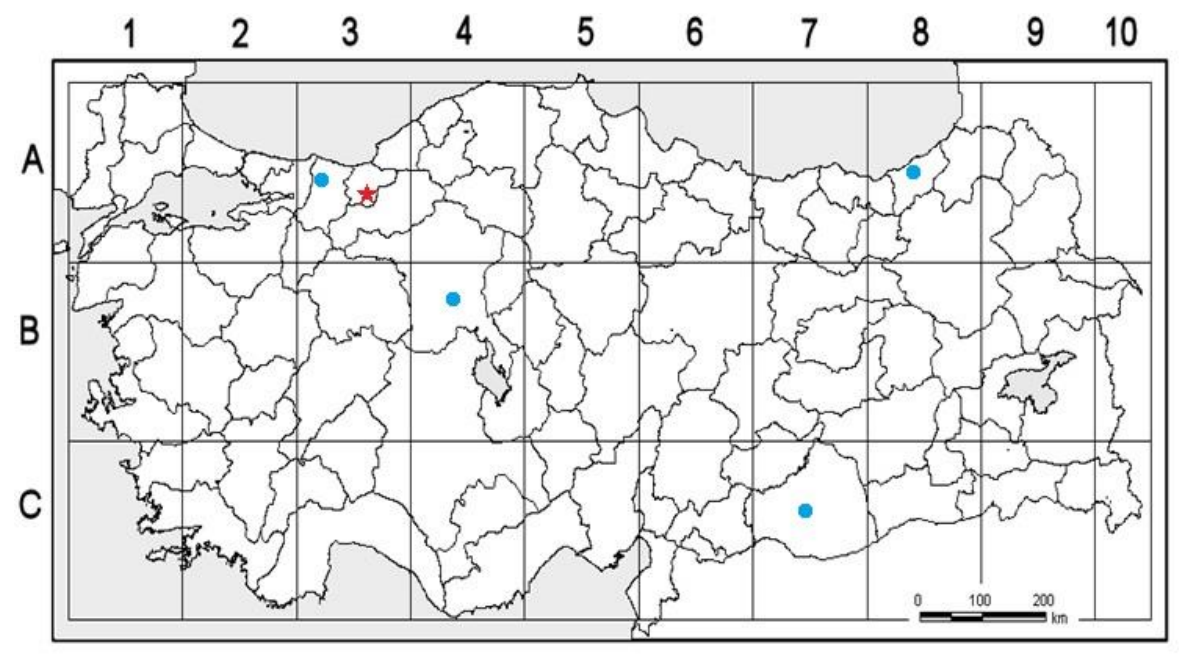

Figure 1. Study area in grid system, distribution of $P$. orientale in study area $(\downarrow)$ and other distributions $(\bigcirc)$ in Turkey.

\section{Results}

Based on the data obtained, a new locality of $P$. orientale in the Western Black Sea Region (Düzce province, Kaynaşlı district) rediscovered with this study, 73 years after the last sample from Urfa in 1947 in Herbarium Turcicum-Ankara (ANK) (Geven et al. 2008). After a new locality of this taxon in Turkey recorded with this study, the general distribution ranges are represented as the Marmara Region, the Central Anatolia Region, the Eastern Black Sea Region, the South East Anatolia Region and latest the Western Black Sea Region in Turkey. Our study and the other distributions of P. orientale in Turkey were given Fig.1.

Habitat: Information about the distributions of the plant in Turkey was obtained from herbarium samples. However, no information about the habitats of the plant was found in Adapazar1 (1936), Ankara (1942) and Urfa (1947) samples. Only in Rize sample (1945), it has been reported that it was collected from the roadside near the stream and a nursery area. In this study area we found that $P$. orientale habitats were ruderal areas, stream edge and the roadsides.

Botanical description of Polygonum orientale (Fig. 2): Annual herb, up to $2 \mathrm{~m}$ tall. Leaves long petioled $(2-10 \mathrm{~cm})$, lamina broadly ovat, $10-18 \times 5-12 \mathrm{~cm}$, base cordat or rounded, decurrent, apex acuminate. Ochrea $2 \times 1.2 \mathrm{~cm}$ tubular, membranous, villous, long ciliate, sometimes with leaflike part at the tip. Inflorescence up to $8 \mathrm{~cm}$, generally terminal, drooping panicula. Peduncul up to $6 \mathrm{~cm}$. 5-6 flowers in 
axil of each ochre alike bract (ochreolae). The large parts of bracteoles (ocreolae) ovat, acuminate, margin ciliate, $5 \times 2 \mathrm{~mm}$. Perianth segments 5, bright pink, pedisel 4-5 mm. Styles 2, connate below, stigmas capitate. Achenes $2,5 \times 3 \mathrm{~mm}$, orbicular, black-brown, polished. Moreover, in addition to these characters, we have added some taxonomic contributions which were pedicels of each flowers in fascicles up to $5 \mathrm{~mm}$, the large parts of bracteoles (ocreolae) ovate and up to $5 \times 2 \mathrm{~mm}$ (Fig. 3) to description.

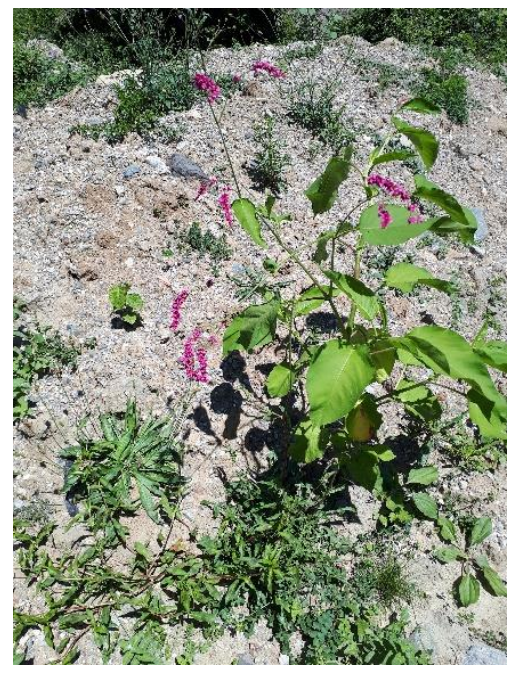

A

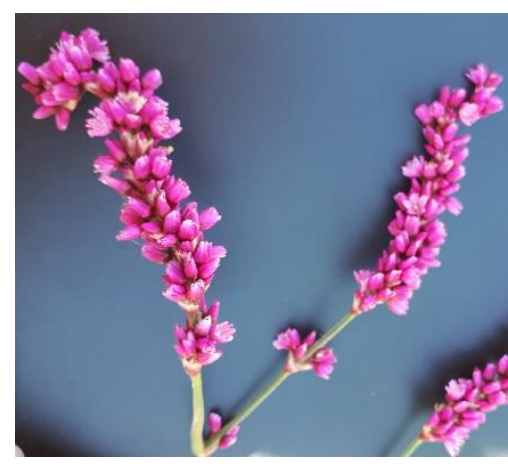

b

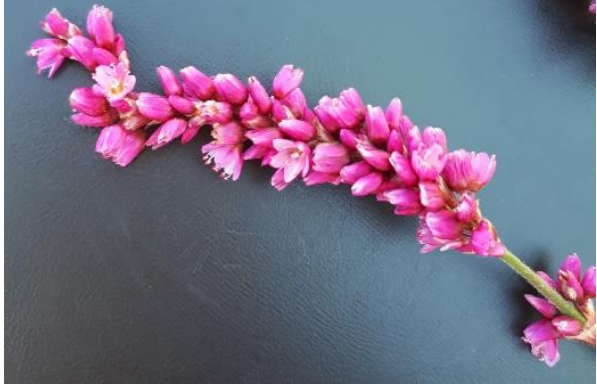

$\mathbf{C}$

Figure 2. Polygonum orientale a) Habitus, b) Inflorescens, c) Flowers (CNeval GÜNEŞ ÖZKAN).

\section{Discussion}

Prior to this study, habitat information of $P$. orientale was very limited in its existing records in Turkey, for this reason the habitat information described in this study can provide an estimate of where a taxon will emerge in the future. The presence of this species on ruderal areas, stream edges and the roadsides has led us to assume that the seeds of the taxon may have been transported to the environment for reasons such as flooding. As a matter of fact, it has been known that plant seeds can be spread to new areas by flood events, irrigation channels or rain and cause serious contaminations (Yazlık et al. 2018). Therefore, we estimate that the taxon was located in different areas than the area in which it was determined. Considering these situations, we would like to emphasize that this taxon should be monitored, especially along the stream. Moreover, literature reviews showed that this species is used in ornamental plant growing and it is found in some agricultural areas as weed (Ferrero \& Vidotto 1998, Hinds Harold \& 


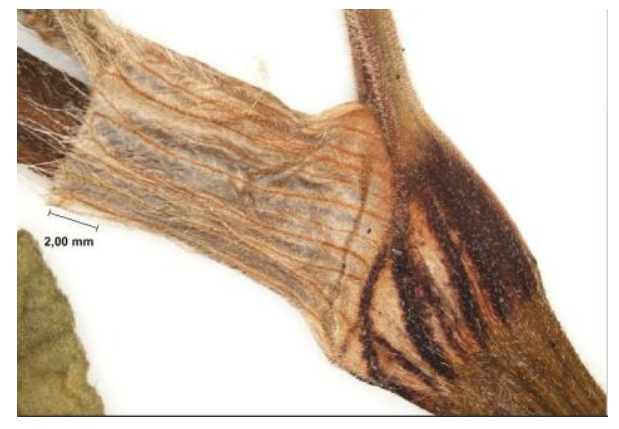

a

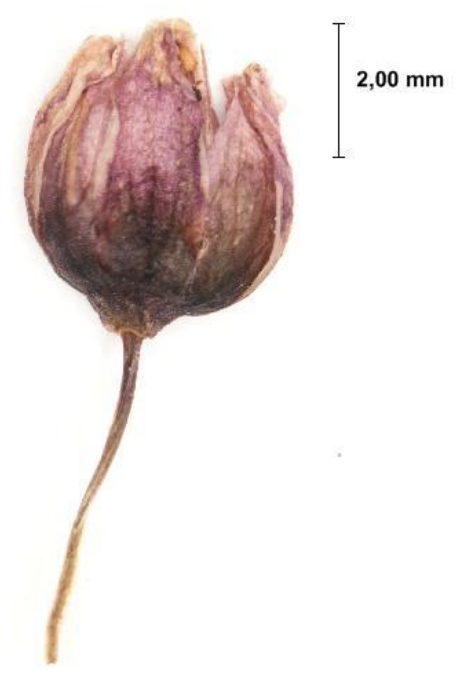

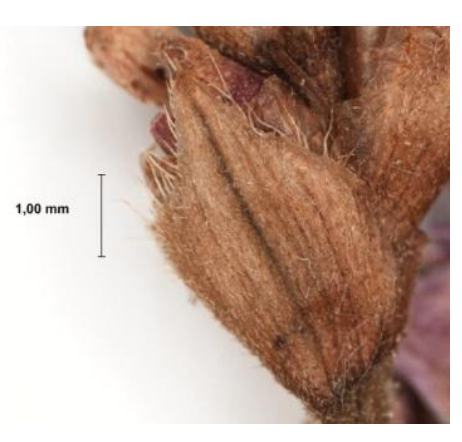

b

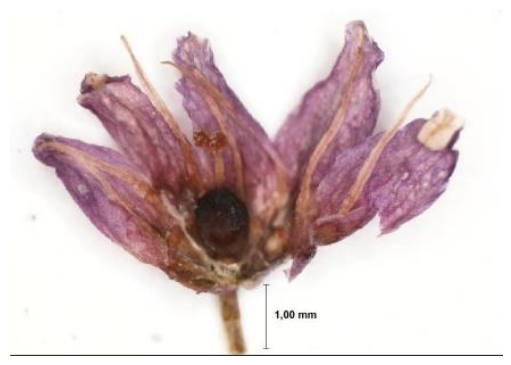

C

$\mathrm{d}$

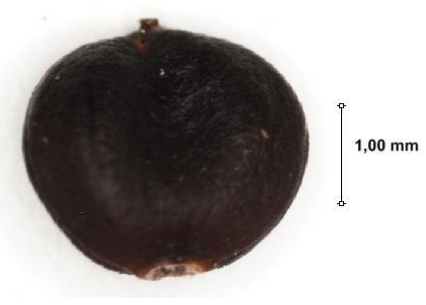

$\mathrm{E}$

Figure 3. Polygonum orientale a) Ochrea, b) Bracteol (ocreolae), c) Flower, d) Ovary, style and stigmas, e) Fruit (CNeval GÜNEŞ ÖZKAN).

Freeman 2020, EPPO 2020). For all these reasons, we can define widespread habitats of $P$. orientale, taking into account the EUNIS habitat classification system (EUNIS 2020), as spread to inland surface water habitats (river edge), artificial or disturbed habitats (roadsides, ruderal habitats, empty areas, waste areas) and agricultural habitats (nurseries and, ornamental plants in cultivated gardens).

Polygonum orientale is widely grown as an ornamental plant (e.g. China, Indian subcontinent, Japan) due to its showy and fragrant flowers, and thus it might easily naturalized in the areas where it is found. However, it was reported that it escapes and becomes weedy from time to time in humid waste areas (Hinds Harold \& Freeman 2020, USDA 2020, EPPO 2020). Taking into account this situation, we 
investigate the use of this species as an ornamental plant in Turkey and we have encountered some commercial seed sales records (ZTBB 2020) in İstanbul province. In this case, the species is likely to be seen in different regions in Turkey as ornamental plants. Ornamental plants have a big share in introducing plants to new areas (Pergl et al. 2016). Therefore, $P$. orientale can be surfaced as naturalized taxa in different regions of Turkey in the near future. Moreover, the presence of $P$. orientale in a different region from previous localities is an indication that this species also may exist in other regions. As a matter of fact, it has been reported (Ferrero \& Vidotto 1998, Burke et al. 2010) that, like other Polygonaceae members, $P$. orientale has features such as high seed-forming ability and lack of soil selectivity, and also seeds can be spread in a variety of ways, such as insects / birds / ruminants or water. That means that this taxon may spread to different areas and establish a wide risk of installation. As a matter of fact, there is also evidence that it may create high risk in this regard. For instance; it is ranked at category 3 in the West Virginia Invasive Plant Species list (WV-DNR 2009), which means it is easily established and spread rapidly in highly invasive species and natural systems. Moreover, alien taxa have the ability to settle in a new area more easily than native taxa (Simberloff et al. 2013), and most of alien plants have been shown strong environmental and socioeconomic impacts (Rumlerová et al. 2016; Yazlik et al. 2018). On the other hand, P. orientale, as with many Polygonaceae members, has attraction to bees, butterflies and birds due to its dense flowers (Ferrero \& Vidotto 1998, Mitra 2010) and it has positive impacts on ecosystem services like animal feed and pollination. For these reasons $P$. orientale alien status should also be considered and habitats should be kept under surveillance based on its impacts types in Turkey.

Lastly, this and similar rediscovery studies (e.g. Çilden et al. 2018) are important for Turkey's geography with high surface areas and multi-mobility (tourism, common transportation point for many countries, etc.), especially for alien taxa. In addition, we believe that studies in this direction will help to develop national flora records and contribute to the use of international common information. Moreover, this taxon was not included in Turkey's alien plant taxa list recorded by Uludağ et al. (2017). Therefore this study also provides an additional taxon to the list of Turkey's alien plant taxa.

\section{Acknowledgements}

We would like to thank Serdar Aslan (Düzce), Tuğrul Körüklü (Ankara) and Mustafa Keskin (İstanbul) due to their support in achieving their related taxon records in Turkey. We also thank the two anonymous reviewers for valuable comments and suggestions. We are thankful to DÜBAP (Turkey) for their support to our study with the project ID: 2018.11.02.731.

\section{References}

Burke, J.M., Sanchez, A., Kron, K., Luckow, M. (2010). Placing the woody tropical genera of Polygonaceae: A hypothesis of character evolution and phylogeny. American Journal of Botany 97:1377-1390.

Çilden, E., Yildirimli, S., Zare, G., Martin-Bravo, S. (2018). Rediscovery of the restricted endemic Reseda balansae (Resedaceae) in Turkey. Phytotaxa 362:87-96.

Davis, P.H. (1967). Polygonaceae: Davis PH (ed.), Flora of Turkey and the East Aegean Islands, Edinburgh University Press, Edinburgh 2: 265.

EPPO (2020). EPPO Global Database Avaliable from: https://gd.eppo.int/taxon/POLOR (accessed: 03 February 2020).

Ferrero, A., Vidotto, F. (1998). Biometrical traits of Polygonum orientale, a potential weed in Italian maize fields. Italian Journal of Agronomy 2: 73-77.

Freeman, C.C., Reveal, J.L. (2005). Flora of North America. Polygonaceae Juss. Available from:http://www.efloras.org/florataxon.aspx?flora_id=1\&taxon_id=10717 (acessed: 11 April 2020). 
GBIF (2020). Persicaria orientalis (L.) Spach in GBIF. GBIF Backbone Taxonomy. Checklist dataset doi: 10.15468/39omei (accessed: 02 April 2020).

Geven, F., Bingöl, Ü., Güney, K. (2008). ANK Herbaryum'u Polygonaceae Familyasının Revizyonu ve Veritabanının Hazırlanması. Kastamonu University Journal of Forestry Faculty 8(1): 67-85.

Güner, A., Aslan, S., Ekim, T., Vural, M. \& Babaç, M.T. (Eds.) (2012). Türkiye Bitkileri Listesi (Damarlı Bitkiler). Nezahat Gökyiğit Botanik Bahçesi ve Flora Araştırmaları Derneği Yayını. İstanbul.

Hinds Harold R. \& Freeman Craig C. (2020). Persicaria orientalis in Flora of North America Editorial Committee (ed.), Flora of North America. Available from: http://www.efloras.org (acssesed: 02 April 2020).

IPNI (2020). Persicaria orientalis (L.) Spach. Available from: http://www.ipni.org (accessed 5 February 2020).

Keskin, M. (2012). Polygonum. Available from: www.bizimbitkiler.org.tr (accessed: 01 February 2020).

Kaufman, S.R., Kaufman, W. (2012). Invasive Plants: A Guide to Identification, Impacts, and Control of Common North American Species 2nd Ed. 458 p.

Linnaeus C. (1753). Species Plantarum Vol. 1, pp. 560, London.

Mitra, B. (2010). Diversity of flower-visiting flies (Insecta: diptera) in India and their role in pollination. Records of the Zoological Survey of India 110: 95-107.

Pergl J., Sádlo J., Petř́k P., Danihelka J., Chrtek J. Jr., Hejda M., Moravcová L., Perglová I., Štajerová K., Pyšek P. (2016). Dark side of the fence: ornamental plants as a source for spontaneous flora of the Czech Republic. Preslia 88: 163-184.

Randall, R.P. (2012). A Global Compendium of Weeds. 2nd Edition. Department of Agriculture and Food, Western Australia, 1124 p.

Rumlerová, Z., Vilà, M., Pergl, J., Nentwig, W., Pyšek, P. (2016). Scoring environmental and socioeconomic impacts of alien plants invasive in Europe. Biological Invasions 18: 3697-3711.

Roskov, Y., Ower, G., Orrell, T., Nicolson, D., Bailly, N., Kirk, P.M., Bourgoin, T., DeWalt, R.E., Decock, W., Nieukerken, E. van, Zarucchi, J., Penev, L., Eds. (2019). Species 2000 \& ITIS Catalogue of Life, 2019 Annual Checklist, Available from: www.catalogueoflife.org/annual-checklist/2019. Species 2000: Naturalis, Leiden, the Netherlands. ISSN 2405-884X. (accessed: 12 June 2020).

Simberloff, D., Martin, J.L., Genovesi, P., Maris, V., Wardle, D.A., Aronson, J., Courchamp, F., Galil, B., GarcíaBerthou, E., Pascal, M., Pyšek, P., Sousa, R., Tabacchi, E., Vila, M. (2013). Impacts of biological invasions: what's what and the way forward. Trends Ecol Evol 28:58-66.

Thiers, B. (2020 [continuously updated]). Index herbariorum, a global directory of public herbaria and associated staff. New York Botanical Garden’s Virtual Herbarium. Available from: http://sweetgum.nybg.org/ih (accessed: 20 July 2020).

TPL (2020). The Plant List Version 1.1. Published on the Internet. Available from: http://www.theplantlist.org/ (accessed: 01 April 2020).

Uludağ, A., Aksoy, N., Yazlık, A., Arslan, Z.F., Yazmış, E., Üremiş, I., Cossu, T.A., Groom, Q., Pergl, J., Pyšek, P., Brundu, G. (2017). Alien flora of Turkey: checklist, taxonomic composition and ecological attributes. NeoBiota 35: 61-85.

USDA (2020). Persicaria orientalis (L.) Spach, Germplasm Resources Information Network (GRIN), Agricultural Research Service (ARS), (accessed: 14 April 2020).

WV-DNR (2009). West Virginia Division of Natural Resources Natural Heritage Program, Invasive Plant Species of West Virginia WV 26241Version. Available 
https://www.wvdnr.gov/Wildlife/Handout\%20Invasive\%20Plants\%20of\%20WV\%202009.pdf (acessed: 12 June 2020).

Yazlık A., Üremiş İ., Uludağ A., Uzun K., Şenol S. G. (2018). Ipomoea triloba: an alien plant threatening many habitats in Turkey. EPPO Bulletin 48(3):589-594.

Yazlık, A., Pergl, J., Pyšek, P. (2018). Impact of alien plants in Turkey assessed by the Generic Impact Scoring System. NeoBiota 39: 31-51.

ZTBB (2020). Zeytinburnu Tıbbi Bitkiler Bahçesi. Avaliable from: http://ztbb.org/koleksiyon/tohumlistesi/ (accessed: 02 April 2020).

Submitted: 22.08.2020 Accepted: 30.09.2020 